\title{
Protection from HIV on electives: questionnaire survey of UK medical schools
}

\author{
Anthea J Tilzey, Jangu E Banatvala
}

Department of Infection (Virology) Guy's, King's, and St Thomas's School of Medicine and Dentistry, London SE1 7EH

Anthea J Tilzey clinical senior lecturer Jangu E Banatvala emeritus professor

Correspondence to: AJ Tilzey anthea.tilzey@

kcl.ac.uk

BMJ 2002;325:1010-1
Elective studies are an important part of the medical curriculum. Sixty to seventy per cent of British medical students (2400-3000 a year) spend their electives in developing countries. In 1999 the BMJ published our survey at one teaching hospital of students returning from electives, focusing on risks from bloodborne virus infections. ${ }^{1}$ In the same edition a survey of all United Kingdom medical schools showed similar concerns and recommended a national policy on protecting medical students, ${ }^{2}$ and an accompanying editorial described students on electives as "unprepared, ill advised, and at risk." The United Kingdom health departments now recommend that healthcare workers, including medical and dental students, intending to work overseas in areas of high HIV prevalence should consider carrying starter packs of HIV postexposure prophylaxis. They also recommend that information on bloodborne virus infection control should be included in the medical curriculum. ${ }^{3}$

\section{Methods and results}

To determine whether these reports ${ }^{12}$ and recommendations ${ }^{3}$ had produced improvement, we designed a questionnaire for medical schools (available on bmj.com), approved by the Council of Heads of Medical Schools. It was sent in November 2000, via deans, to those providing advice on electives in all 23 British medical schools. Forms were returned by March 2001.

All but three schools had changed their elective policies with regard to bloodborne viruses as a result of our paper or the health department's advice (table). No school forbade electives in areas of high HIV prevalence. Some advised restrictions on clinical practice in areas of high HIV endemicity (13) or poor standards of supervision or infection control (15). Five schools did not recommend HIV postexposure prophylaxis starter packs, although two of these advised students against any invasive procedures, including venepuncture, in the absence of local needlestick injury protocols offering postexposure prophylaxis. Some schools did not provide written advice on vaccinations or antimalarial prophylaxis, some did not provide an immunisation service, and one provided neither. General health hazards reported during the previous three years were (in order of frequency): assault, malaria, dysentery, road traffic injuries, and schistosomiasis. Three students died, one while diving, one in a road crash, and one through carbon monoxide poisoning from a faulty gas water heater.

\section{Comment}

Although some medical schools still do not recommend HIV postexposure prophylaxis for students on electives, we think that it should be provided when indicated. Students are vaccinated against hepatitis B, and education about the risks and prevention of bloodborne viruses and the follow up of needlestick injuries, whether at home or abroad, is important throughout the curriculum. Although students on electives are more likely to be injured through trauma and violence or infected with malaria, we concentrated on the risks from HIV, since these have again been highlighted by two recent studies. One showed that in parts of sub-Saharan Africa half of adult male inpatients are HIV positive and $56 \%$ of interns had experienced penetrating injuries, $18 \%$ from HIV positive patients. ${ }^{4}$ One UK medical school reported that 38 out of 103 students had had significant exposure to potentially infected blood on their electives. ${ }^{5}$ Although

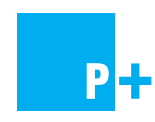

The medical school questionnaire appears on bmi.com

\begin{tabular}{|c|c|c|}
\hline Question & No of respondents answering yes & Comments \\
\hline $\begin{array}{l}\text { (1) Do you provide written advice on bloodborne viral } \\
\text { infections (BBVs)? }\end{array}$ & 23 & $\begin{array}{l}\text { Produced by mixed groups, eg virologists, } \\
\text { microbiologists, infectious disease consultants, } \\
\text { occupational health physicians, elective advisers }\end{array}$ \\
\hline (2) Did you read our paper in the 1999 BMJ? & 23 & \\
\hline $\begin{array}{l}\text { (3) Did you change your elective policy with regard to } \\
\text { bloodborne viral infections as a result? }\end{array}$ & 15 & \multirow[b]{2}{*}{$\begin{array}{l}\text { Only three schools did not change their policy as a } \\
\text { result of either (3) or (4) }\end{array}$} \\
\hline $\begin{array}{l}\text { (4) Did you change your elective policy with regard to } \\
\text { bloodborne viral infections following publication of } \\
\text { the DoH guidelines in July 2000? }\end{array}$ & 15 & \\
\hline $\begin{array}{l}\text { (5) Do you advise restrictions on clinical attachments } \\
\text { in areas with a relatively high prevalence of HIV? }\end{array}$ & 13 & $\begin{array}{l}\text { Restrictions included trauma, obstetrics, and surgery, } \\
\text { particularly deep pelvic and abdominal, thoracic, and } \\
\text { orthopaedic }\end{array}$ \\
\hline $\begin{array}{l}\text { (6) Do you advise restrictions on clinical attachments } \\
\text { in areas with poor standards of infection control or } \\
\text { supervision? }\end{array}$ & 15 & $\begin{array}{l}\text { Two schools advised against any invasive procedures, } \\
\text { including venepuncture, in the absence of a } \\
\text { needlestick protocol offering HIV postexposure } \\
\text { prophylaxis }\end{array}$ \\
\hline $\begin{array}{l}\text { (7) Do you advise students to take starter packs of } \\
\text { HIV postexposure prophylaxis if appropriate? }\end{array}$ & 18 & $\begin{array}{l}\text { Zidovudine and lamivudine (10), } \\
\text { triple therapy (4), zidovudine (2), } \\
\text { unspecified (2); student's pay (13) }\end{array}$ \\
\hline $\begin{array}{l}\text { (8) Do you provide written advice on vaccinations or } \\
\text { antimalarials? }\end{array}$ & 18 & \multirow{2}{*}{ Only one school provided neither of (8) or (9) } \\
\hline (9) Do you provide a vaccination service? & 18 & \\
\hline
\end{tabular}


we respect the views of schools who do not advise postexposure prophylaxis because self prescribing of potentially toxic drugs without supervision is too risky, a seven day course is unlikely to cause serious side effects and starter packs give students time to seek expert advice and follow up.

Schools should balance the educational advantages of electives with the health risks involved. At the very least they should provide updated advice on bloodborne virus infections, travel vaccinations, and general hazards such as unprotected sexual intercourse, assault, and political instability. Advice could be centrally provided.

We thank the Council of Heads of Medical Schools, particularly the secretary, Mr Michael Powell, for help.

Contributors: AJT designed the questionnaire, analysed results, and wrote the paper jointly with JEB, who also liaised with the
Council of Heads of Medical Schools. AJT is guarantor. An unabridged version of this paper is available on the CHMS website (www.chms.ac.uk)

Funding: Divisional resources.

Competing interests: None declared.

1 Gamester CF, Tilzey AJ, Banatvala JE. Medical students' risk of infection with blood borne viruses at home and abroad; questionnaire survey. $B M J$ 1999;318:158-60

2 Moss PJ, Beeching NJ. Provision of health advice for UK medical students planning to travel overseas for their elective study period: questionnaire survey. BMJ 1999;318:161-2.

3 UK Health Departments. HIV post-exposure prophylaxis: guidance from the UK chief medical officers'expert advisory group on AIDS. London: $\mathrm{DoH}, 2000$.

4 Karstaedt AS, Pantanowitz L. Occupational exposure of interns to blood in an area of high HIV seroprevalence. S Afr Med J 2001;91:57-61.

5 Franklin GS, Gray K, Nathwani D. Provision of drugs for post-exposure prophylaxis of HIV for medical students on overseas electives. J Infect 2001;43:191-4.

(Accepted 18 April 2002)

\title{
Maternal smoking and risk of hypertrophic infantile pyloric stenosis: 10 year population based cohort study
}

\author{
Henrik Toft Sørensen, Bente Nørgård, Lars Pedersen, Helle Larsen, Søren Paaske Johnsen
}

Infantile hypertrophic pyloric stenosis affects 0.5 to 3.0 per 1000 live births. ${ }^{12}$ The aetiology is unclear, but family history and sex distribution seem important and might indicate a genetic role. ${ }^{3}$ However, a recently reported fall in the incidence of infantile hypertrophic pyloric stenosis suggests that environmental factors are also important. ${ }^{4}$ During the last decade a similar reduction in the proportion of pregnant women who smoke was reported in Denmark, ${ }^{5}$ raising the possibility that maternal smoking is a risk factor for infantile hypertrophic pyloric stenosis. This hypothesis is supported by the reported ecological association between infantile hypertrophic pyloric stenosis and sudden infant death syndrome. ${ }^{1}$ Maternal smoking is also a risk factor for sudden infant death syndrome, and we therefore examined whether maternal smoking was a risk factor for infantile hypertrophic pyloric stenosis in a population based Danish cohort.

\section{Methods and results}

We conducted the study between 1 January 1991 and 31 December 2000 in the Danish county of North Jutland and included data on all women who delivered a live infant after 28 weeks' gestation. The county birth registry contains information on all births since 1 January 1991. The main data comprise maternal age, self reported smoking status at the first visit to the midwife, birth order, gestational age, length and weight of neonates at birth, civil status, and civil registry numbers for both mother and child.

We identified all cases of infantile hypertrophic pyloric stenosis from the county hospital discharge registry, which contains data on all discharges from the hospitals since 1977, the civil registry number, dates of admission and discharge, surgical procedures per- formed, and up to 20 diagnoses classified according to the international classification of diseases (ICD-8 until the end of 1993 and then ICD-10). The codes for infantile hypertrophic pyloric stenosis were 750.19 (ICD-8) and Q40.0 (ICD-10). The civil registry numbers were used to link the records in both registries.

We used SAS version 8.02 for logistic regression. We estimated the risk of infantile hypertrophic pyloric stenosis among infants born to smoking mothers and non-smoking mothers adjusted for maternal age, civil status, birth order, and sex of the child.

There were 57996 births during the study, and $16725(28.8 \%)$ mothers smoked. We identified 78 cases of infantile hypertrophic pyloric stenosis, yielding a cumulative incidence of $1.3 \%$. Thirty five cases $(0.2 \%)$ occurred among maternal smokers compared with $43(0.1 \%)$ among maternal nonsmokers, giving a relative risk of 2.0. The adjusted odds ratio was also $2.0(95 \%$ confidence interval 1.3 to 3.1 , table). The correlation between the proportion of smokers and annual incidence of infantile hypertrophic pyloric stenosis per birth year was 0.65 (Spearman's $\tau=0.65, \mathrm{P}=0.04)$. The highest incidence was $0.22 \%$ in 1991 (33\% were smokers), the lowest $0.05 \%$ in 1997 (28\% smokers).

\section{Comment}

Our data suggest that maternal smoking is a risk factor for infantile hypertrophic pyloric stenosis. We cannot determine whether the association is caused by smoking during pregnancy or postnatally-that is, through breast milk or passive smoking. We were able to adjust for some risk factors, but confounding by unknown factors associated with smoking cannot be ruled out. $\begin{array}{ll}\text { Department of } & \text { Clinical } \\ \text { Epidemiology, } \\ \text { Aarhus University } \\ \text { Hospital, 8000 } \\ \text { Aarhus C, Denmark }\end{array}$ 